\title{
Pengaruh Metode Pembelajaran Mind Mapping dan Jenis Kelamin Terhadap Hasil Belajar Matematika
}

Author:
Dimas Aji Saputro $^{1}$
Dinawati Trapsilasiwi $^{2}$
Susi Setiawani

Affiliation:
1,2,3 University of Jember, ast
Java, Indonesia
Corresponding author:
Dimas Aji Saputro,
Dimasaji920@ gmail.com
Dates:
Received: $23 / 2 / 2021$
Accepted: $2 / 3 / 2021$
Published: $16 / 3 / 2021$

\begin{abstract}
Abstrak. Penelitian ini bertujuan untuk mengetahui pengaruh metode pembelajaran mind mapping dan jenis kelamin terhadap hasil belajar matematika. Hasil belajar siswa yang diukur hanya pada sub pokok bahasan sifat-sifat, luas, dan keliling segi empat. Soal untuk mengukur hasil belajar siswa merupakan soal materi tentang bangun datar segiempat. Penelitian ini merupakan penelitian eksperimen kuasi. Cara pengambilan sampel menggunakan teknil purpose sampling. Populasi penelitian ini adalah seluruh siswa kelas VIII SMP Negeri 10 Jember dan sampel penelitian adalah siswa kelas VIII E sebagai kelas eksperimen dan siswa kelas VIII A sebagai kelas kontrol. Metode pengujian hipotesis yang digunakan adalah $\mathrm{Uji} \mathrm{T}$ (Independent Sample T-test). Berdasarkan hasil analisis data, diperoleh nilai $\mathrm{t}_{\text {hitung }} \geq \mathrm{t}_{\text {tabel }}(2,374 \geq 1,670)$ untuk pengaruh metode pembelajaran mind mapping. Berdasarkan hasil perhitungan tersebut dapat disimpulkan bahwa $\mathrm{H}_{0}$ ditolak dan $\mathrm{H}_{1}$ diterima yang artinya ada pengaruh metode pembelajaran mind mapping terhadap hasil belajar matematika. Pada pengaruh jenis kelamin diperoleh nilai $t_{\text {hitung }} \geq t_{\text {tabel }}(0,402 \leq 1.692)$. Berdasarkan hasil perhitungan tersebut dapat disimpulkan bahwa $\mathrm{H}_{0}$ diterima dan $\mathrm{H}_{1}$ ditolak yang artinya tidak ada pengaruh jenis kelamin terhadap hasil belajar matematika.
\end{abstract}

Kata kunci: metode pembelajaran mind mapping, jenis kelamin, hasil belajar

\begin{abstract}
This study aims to determine the effect of mind mapping learning methods and gender on mathematics learning outcomes. Student learning outcomes that are measured only in the sub-topic of the properties, area, and perimeter of a flat shape. The question for measuring student learning outcomes is a matter of material about square shapes. This research is a quasi experimental research with purpose sampling design. The population of this research was all students of class VIII SMP Negeri 10 Jember and the research sample was students of class VIII E as the experimental class and class VIII A students as the control class. The hypothesis testing method used is the T test (Independent Sample T-test). Based on the results of data analysis, the value of tcount $\geq$ ttable $(2,374 \geq 1,670)$ was obtained for the effect of the mind mapping learning method. Based on the results of these calculations, it can be concluded that $H_{0}$ is rejected and $H_{1}$ is accepted, which means that there is an effect of the mind mapping learning method on mathematics learning outcomes. On the influence of gender, the value of $t$ count $\geq t$ table $(0.402 \leq 1.692)$ was obtained. Based on the results of these calculations it can be concluded that $\mathrm{HO}$ is accepted and $\mathrm{HI}$ is rejected, which means there is no effect of gender on mathematics learning outcomes.
\end{abstract}

Keywords: mind mapping learning methods, gender, learning outcomes

\section{JoMEaL}

Copyright:

This work is licensed under a Creative Commons Attribution-ShareAlike 4.0 International License.

Read online:

https://jurnal.unej.ac.id/index.php/JOMEAL/index or scan barcode beside.

How to cite this article:

Saputro, D., Trapsilasiwi, D., \& Setiawani, S. (2021). Pengaruh Metode Pembelajaran Mind Mapping dan Jenis Kelamin Terhadap Hasil Belajar Matematika. Journal of Mathematics Education and Learning, 1(1), 1-8. Retrieved from https://jurnal.unej.ac.id/index.php/JOMEAL/article/view/24370 


\section{Pendahuluan}

Pendidikan merupakan bagian terpenting dalam proses pembangunan dari suatu negara berkembang seperti di Indonesia. UU No. 20 tahun 2003 tentang pendidikan di Indonesia menyatakan bahwa pendidikan adalah usaha sadar untuk mewujudkan suasana belajar dan proses pembelajaran agar peserta didik secara aktif mengembangkan potensi dirinya untuk memiliki kekuatan spiritual keagamaan, pengendalian diri, kepribadian, kecerdasan, akhlak mulia, serta keterampilan yang diperlukan dirinya, masyarakat, bangsa dan Negara (Depdiknas, 2003). Pendidikan di Indonesia bertujuan untuk meningkatkan kualitas sumber daya manusia. Peningkatan sumber daya manusia nantinya diharapkan dapat menciptakan generasi baru manusia Indonesia yang berkualitas dan dapat bersaing di dunia internasional (Hasbullah, 2005).

Proses usaha meningkatkan mutu pendidikan di Indonesia tentunya dipengaruhi oleh upaya guru sebagai pendidik dalam pencapaian tujuan pendidikan yang diharapkan. Upaya yang dilakukan oleh seorang guru untuk meningkatkan mutu pendidikan merupakan hal yang sangat penting. Dibutuhkan inovasi-inovasi baru bagi guru dalam hal pengajaran sehingga pembelajaran yang dilakukan dapat lebih bermakna. Pada kenyataannya banyak guru yang telah puas dengan metode mengajar yang biasa dilakukannya. Mereka merasa tidak perlu untuk melakukan inovasi-inovasi baru dalam pengajaran. Hal demikianlah yang menyebabkan pendidikan di Indonesia kurang berkembang.

Mind mapping merupakan salah satu inovasi dalam pembelajaran yang efektif. Mind mapping adalah suatu teknik visual yang dapat menyelaraskan proses belajar dengan cara kerja alami otak. Mind mapping dikatakan sesuai dengan kerja alami otak karena pembuatannya menggunakan prinsipprinsip brain managemen. Sehingga akan mudah untuk menempatkan informasi ke dalam otak dan mengambil informasi itu ketika dibutuhkan. Kelebihan menggunakan Mind mapping adalah sebagai berikut:

1) dapat melihat gambaran secara menyeluruh;

2) dapat melihat detailnya tanpa kehilangan benang merah antar topik;

3) terdapat pengelompokan informasi;

4) menarik perhatian mata dan tidak membosankan

5) memudahkan berkonsentrasi;

6) proses pembuatannya menyenangkan karena melibatkan gambar, warna dan lain-lain;

Agar tujuan dari penggunaan Mind mapping pada siswa dapat terpenuhi, maka diperlukan taraf intelegensi yang tinggi pula. Menurut beberapa pakar, taraf intelegensi seseorang dapat digolongkan berdasarkan jenis kelamin. Setiap siswa baik itu laki-laki maupun perempuan memiliki kecerdasan yang berbeda-beda. Muncul anggapan bahwa pada umumnya kecerdasan siswa laki-laki terletak pada kekreatifitasannya (lebih dominan menggunakan otak kanan) sedangkan siswa perempuan pada umumnya memiliki kecerdasan di bidang akademik (lebih dominan menggunakan otak kiri). Sebenarnya anggapan tersebut muncul karena perbedaan ukuran bagian-bagian otak laki-laki dan perempuan yang berbeda[3].

Berdasarkan penelitian Kasanah (2012) yang berjudul "Pengaruh Kolaborasi Pembelajaran Mind mapp dan Problem possing Terhadap Prestasi Belajar Matematika Pada Materi Segitiga Siswa Kelas VIII SMPN 1 Sumbergempol”, menunjukkan kesimpulan bahwa ada pengaruh positif dalam pembelajaran Mind mapp dan ploblem possing terhadap prestasi belajar matematika.

Penelitian selanjutnya dilakukan oleh Ekawati dan Wulandari dengan judul "Perbedaan Jenis Kelamin Terhadap Kemampuan Siswa Dalam Mata Pelajaran Matematika (Study Kasus Sekolah 
Dasar)" memberikan simpulan bahwa tidak ada pengaruh perbedaan jenis kelamin siswa laki-laki dan siswa perempuan dalam pokok bahasan geometri (Ekawati dan Wulandari, 20011).

Perbedaan antara penelitian terdahulu dengan penelitian sekarang yaitu pada materi yang akan disampaikan. Perbedaan penelitian yang dilakukan Khasanah dan Ekawati adalah menggunakan metode diskriptif, sedangkan dalam penelitian ini digunakan metode kuantitatif. Variabel bebas yang digunakan adalah metode pembelajaran Mind mapping dan jenis kelamin. Materi yang digunakan dalam penelitian adalah Bangun Datar. Penelitian dilaksa nakan di SMP Negeri 10 Jember.

Berdasarkan uraian diatas, maka rumusan masalah dari penelitian ini adalah :

1. Adakah pengaruh metode pembelajaran Mind mapping terhadap hasil belajar Matematika?

2. Seberapa besar pengaruh metode pembelajaran Mind mapping terhadap hasil belajar Matematika?

3. Adakah pengaruh jenis kelamin terhadap hasil belajar Matematika?

Seberapa besar pengaruh jenis kelamin terhadap hasil belajar Matematika?

\section{Metode Penelitian}

Jenis penelitian ini adalah kuasi experiment atau eksperimen semu. Penelitian eksperimen adalah metode penelitian yang digunakan untuk mengetahui pengaruh dari suatu tindakan atau perlakuan yang sengaja dilakukan terhadap suatu kondisi tertentu. Cara untuk menentukan pengaruh perlakuan terhadap kelas eksperimen dan kelas kontrol adalah dengan membandingkan rata-rata nilai hasil belajar antara kelas esperiment dan kelas kontrol. Kelas eksperimen diberi perlakuan metode pembelajaran mind mapping, sedangkan kelas kontrol menggunakan metode pembelajaran diskusi dan ceramah. Tempat penelitian ini adalah SMP Negeri 10 Jember. Populasi penelitian ini adalah seluruh siswa kelas VIII SMP Negeri 10 Jember tahun ajaran 2020/2021 yang terdiri dari 5 kelas. Pengambilan sampel dilakukan secara purpose sampling dan diperoleh kelas VIII E sebagai kelas eksperimen dan kelas VIII A sebagai kelas kontrol.

Metode pengumpulan data yang digunakan adalah metode dokumentasi, dan tes. Instrumen penelitian yang digunakan adalah RPP dan soal tes hasil belajar. Soal yang digunakan untuk penelitian ini merupakan soal matematika dengan sub pokok bahasan sifat-sifat, luas, dan keliling segiempat. Validasi dilakukan oleh dua orang dosen program studi Pendidikan Matematika Universitas Jember dan satu guru mata pelajaran matematika SMP Negeri 10 Jember. Analisis data yang digunakan adalah uji T (Independent Sample T-Test) dimana uji ini akan membandingkan rata-rata dari dua sampel yang tidak berhubungan satu dengan yang lainnya.

Hipotesis yang diajukan sebagai berikut.

1) Hasil belajar

Hasil belajar yang diukur dalam penelitian ini adalah hasil belajar pada ranah kognitif siswa.

Pengolahan nilai pada ranah kognitif adalah sebagai berikut

$$
\mathrm{NK}=\frac{b}{B} \times 100 \%
$$

Keterangan:

NK = Nilai Kognitif Siswa

$\mathrm{b}=$ jumlah skor yang diperoleh

$\mathrm{B}=$ jumlah skor maksimum 
2) Uji Hipotesis pemgaruh metode mind mapping terhadap hasil belajar Matematika

a. Uji Normalitas

Uji normalitas bertujuan untuk mengetahui data nilai ujian matematika semester ganjil mata pelajaran matematika dari populasi berdistribusi normal atau tidak. Uji normalitas menggunakan metode Kolmogorov smirnov.

Pengambilan keputusan dari uji ini adalah sebagai berikut:

Nilai asymp. Sig (2-tailed) $\geq 0,05$ maka berdistribusi normal;

Nilai asymp. Sig (2-tailed) $<0,05$ maka tidak berdistribusi normal.

b. Uji homogenitas

Uji homogenitas ini dilakukan untuk mengetahui homogen atau tidaknya data ujian matematika semester ganjil pada mata pelajaran matematika. Pengambilan keputusan dari uji ini adalah sebagai berikut:

Nilai Sig. $\geq 0,05$ maka disimpulkan bahwa varian homogen;

Nilai Sig. $<0,05$ maka disimpulkan bahwa varian tidak homogen.

c. Kriteria Pengujian

Teknik t-test adalah teknik statistic yang dipergunakan untuk menguji signifikasi perbedaan dua buah mean yang berasal dari dua buah distribusi Rumus uji t sebagai berikut:

Keterangan:

$$
t-t e s t=\frac{\bar{X}_{E}-\bar{X}_{K}}{\left|\frac{S D_{E}{ }^{2}}{N_{E}-1}\right|+\left|\frac{S D_{K}{ }^{2}}{N_{K}-1}\right|}
$$

$\bar{X}_{E}=$ mean pada distribusi kelas eksperimen

$\bar{X}_{K}=$ mean pada distribusi kelas kontrol

$S D_{K}=$ nilai varian pada distribusi kelas eksperimen

$S D_{K}=$ nilai varian pada distribusi kelas kontrol

$N_{E}=$ jumlah individu pada kelas eksperimen

$N_{K}=$ jumlah individu pada kelas kontrol

d. Hipotesis Statistik

$H_{0}: \overline{X_{E}} \leq \overline{X_{K}}$ (tidak ada pengaruh metode pembelajaran mind mapping terhadap hasil belajar matematika).

$H_{1}: \overline{X_{E}}>\overline{X_{K}}$ (ada pengaruh metode pembelajaran mind mapping terhadap hasil belajar matematika).

Jika nilai signifikasi $\leq 0,05$ maka hipotesis nihil (H0) ditolak dan hipotesis alternatif (H1) diterima Jika nilai signifikasi > 0,05 maka hipotesis nihil (H0) diterima dan hipotesis alternatif (H1) ditolak Dengan kriteria pengambilan keputusan

Jika thitung $<$ ttabel atau nilai signifikan ( $\rho$-value) $>0,05$ maka H0 diterima

Jika thitung $\geq$ ttabel atau nilai signifikan $(\rho$-value $) \leq 0,05$ maka $\mathrm{H} 0$ ditolak.

3. Uji Hipotesis pemgaruh Jenis kelamin terhadap hasil belajar Matematika

a. Uji Normalitas

Uji normalitas bertujuan untuk mengetahui data nilai ujian matematika semester ganjil mata pelajaran matematika dari populasi berdistribusi normal atau tidak. Uji normalitas menggunakan metode Kolmogorov smirnov.

Pengambilan keputusan dari uji ini adalah sebagai berikut:

Nilai asymp. Sig (2-tailed) $\geq 0,05$ maka berdistribusi normal;

Nilai asymp. Sig (2-tailed) $<0,05$ maka tidak berdistribusi normal. 
b. Uji homogenitas

Uji homogenitas ini dilakukan untuk mengetahui homogen atau tidaknya data ujian matematika semester ganjil pada mata pelajaran matematika. Pengambilan keputusan dari uji ini adalah sebagai berikut:

Nilai Sig. $\geq 0,05$ maka disimpulkan bahwa varian homogen;

Nilai Sig. $<0,05$ maka disimpulkan bahwa varian tidak homogen.

c. Kriteria Pengujian

Teknik t-test adalah teknik statistic yang dipergunakan untuk menguji signifikasi perbedaan dua buah mean yang berasal dari dua buah distribusi Rumus uji t sebagai berikut:

Keterangan:

$$
t-t e s t=\frac{\bar{X}_{E}-\bar{X}_{K}}{\left|\frac{S D_{E}{ }^{2}}{N_{E}-1}\right|+\left|\frac{S D_{K}{ }^{2}}{N_{K}-1}\right|}
$$

$\bar{X}_{E}=$ mean pada distribusi kelas eksperimen

$\bar{X}_{K}=$ mean pada distribusi kelas kontrol

$S D_{K}=$ nilai varian pada distribusi kelas eksperimen

$S D_{K}=$ nilai varian pada distribusi kelas kontrol

$N_{E}=$ jumlah individu pada kelas eksperimen

$N_{K}=$ jumlah individu pada kelas kontrol

d. Hipotesis Statistik

$H_{0}: \overline{X_{E}} \leq \overline{X_{K}}$ (tidak ada pengaruh metode pembelajaran mind mapping terhadap hasil belajar matematika).

$H_{1}: \overline{X_{E}}>\overline{X_{K}}$ (ada pengaruh metode pembelajaran mind mapping terhadap hasil belajar matematika).

Jika nilai signifikasi $\leq 0,05$ maka hipotesis nihil (H0) ditolak dan hipotesis alternatif (H1) diterima

Jika nilai signifikasi > 0,05 maka hipotesis nihil (H0) diterima dan hipotesis alternatif (H1) ditolak

Dengan kriteria pengambilan keputusan

Jika thitung < ttabel atau nilai signifikan $(\rho$-value $)>0,05$ maka H0 diterima

Jika thitung $\geq$ ttabel atau nilai signifikan $(\rho$-value $) \leq 0,05$ maka H0 ditolak.

\section{Hasil dan Pembahasan}

Penelitian dilakukan sebanyak dua kali pertemuan. Pertemuan pertama diberi metode pembelajaran pada masing-masing kelas kemudian pertemuan kedua diberikan tes hasil belajar untuk masing-masing kelas eksperimen dan kelas kontrol. Beberapa hasil mind mapping siswa sebagai berikut.

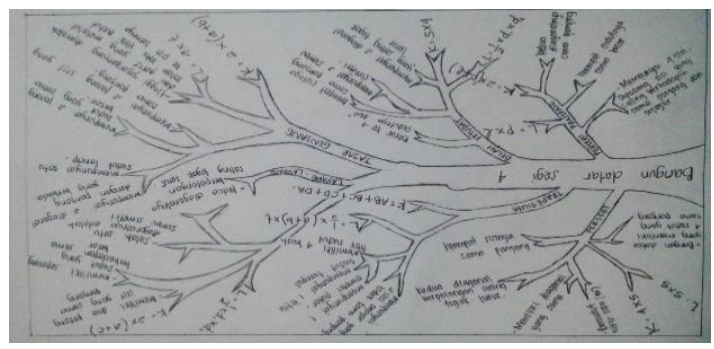

Gambar 1. mind mapping S01 


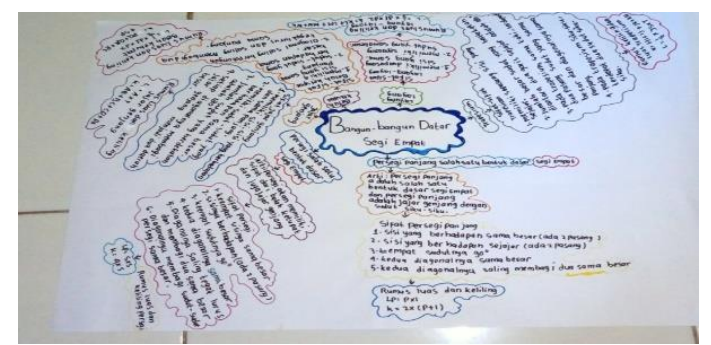

Gambar 2. mind mapping S02

Data tes hasil belajar pada kedua kelas dapat dilihat pada Tabel 1.

Tabel 1. Data Tes Hasil Belajar untuk Metode Pembelajaran Mind Mapping

\begin{tabular}{|c|c|c|}
\hline Kelas & Deskripsi Statistik & THB \\
\hline \multirow{4}{*}{ Eksperimen } & Mean & 82,06 \\
\cline { 2 - 3 } & Standar deviasi & 9,124 \\
\cline { 2 - 3 } & Nilai tertinggi & 100 \\
\cline { 2 - 3 } Kontrol & Nilai terendah & 78 \\
\cline { 2 - 3 } & Mean & 76,06 \\
\cline { 2 - 3 } & Standar deviasi & 11,297 \\
\cline { 2 - 3 } & Nilai tertinggi & 80 \\
\cline { 2 - 3 } & Nilai terendah & 63 \\
\hline
\end{tabular}

Tabel 2. Data Tes Hasil Belajar untuk Pengaruh Jenis Kelamin

\begin{tabular}{|c|c|c|}
\hline Kelas eksperimen & Deskripsi Statistik & THB \\
\hline \multirow{3}{*}{$\begin{array}{c}\text { Jenis kelamin laki- } \\
\text { laki }\end{array}$} & Mean & 82,5 \\
\cline { 2 - 3 } & Standar deviasi & 11,39 \\
\cline { 2 - 3 } & Nilai tertinggi & 100 \\
\hline \multirow{3}{*}{$\begin{array}{c}\text { Jenis kelamin } \\
\text { perempuan }\end{array}$} & Nilai terendah & 78 \\
\cline { 2 - 3 } & Mean & 83,94 \\
\cline { 2 - 3 } & Standar deviasi & 9,155 \\
\cline { 2 - 3 } & Nilai tertinggi & 100 \\
\hline
\end{tabular}

Nilai tes hasil belajar yang telah didapatkan kemudian dilakukan uji normalitas dan homogenitas sebelum dilakukan uji T. Hasil perhitungan normalitas dan homogenitas tes hasil belajar dapat dilihat pada Tabel 3.

Tabel 3. Normalitas dan Homogenitas Data Tes Hasil Belajar Metode Mind Mapping

\begin{tabular}{|c|c|c|c|}
\hline THB & Eksperimen & Kontrol & Ket. \\
\hline Asymp. Sig (2-tailed) & 0,714 & 0,911 & Normal \\
\hline $\begin{array}{c}\text { Nilai Sig. (Levene's Test For } \\
\text { Equality of Variance }\end{array}$ & \multicolumn{2}{|c|}{0,213} & Homogen \\
\hline
\end{tabular}

Tabel 4. Normalitas dan Homogenitas Data Tes Hasil Belajar Untuk Jenis Kelamin pada Kelas Esperimen

\begin{tabular}{|c|c|c|c|}
\hline THB & $\begin{array}{c}\text { Jenis kelamin } \\
\text { laki-laki }\end{array}$ & $\begin{array}{c}\text { Jenis kelamin } \\
\text { perempuan }\end{array}$ & Ket. \\
\hline Asymp. Sig (2-tailed) & 0,986 & 0,660 & Normal \\
\hline
\end{tabular}




\begin{tabular}{|c|c|c|c|}
\hline THB & $\begin{array}{c}\text { Jenis kelamin } \\
\text { laki-laki }\end{array}$ & $\begin{array}{c}\text { Jenis kelamin } \\
\text { perempuan }\end{array}$ & Ket. \\
\hline $\begin{array}{l}\text { Nilai Sig. (Levene's Test } \\
\text { For Equality of Variance }\end{array}$ & \multicolumn{2}{|c|}{0,445} & Homogen \\
\hline
\end{tabular}

Perhitungan uji normalitas menggunakan Kolmogorov-Smirnov pada soal tes hasil belajar kelas kontrol dan kelas esperiment menunjukkan bahwa data tersebut berdistribusi normal. Hal ini dapat dilihat pada nilai signifikan (Asymp. Sig. (2-tailed)) pada kelas eksperimen yaitu 0,714 dan kelas kontrol yaitu 0,911 , dimana masing-masing nilai tersebut $\geq 0,05$ sehingga data tersebut berdistribusi normal. Nilai signifikan (Asymp. Sig. (2-tailed)) pada kelas eksperimen yang berjenis kelamin lakulaki adalah 0,986 dan pada kelas eksperimen yang berjenis kelamin perempuan adalah 0,660 dimana kedua nilai tersebut $\geq 0,05$ sehingga data tersebut juga berdistribusi normal.

Hasil perhitungan uji homogenitas menggunakan Levene Test pada Tabel 3 menunjukkan nilai signifikan Levene Test sebesar 0,213 pada kelas esperimen dan kelas kontrol dan 0,445 pada kela esperimen berdasarkan jenis kelamin. Nilai tersebut masing-masing $\geq 0,05$ sehingga kedua data tersebut homogen. Langkah yang dilakukan setelah uji normalitas dan homogenitas adalah Uji $\mathrm{T}$ untuk mengetahui keefektifan pembelajaran kolaboratif dengan media permainan amplop berhadiah. Uji T yang dilakukan adalah uji independent sample test, dimana uji ini akan membandingkan ratarata dari dua sampel yang tidak berhubungan satu dengan yang lainnya.

Tabel 5. Hasil Uji T (Independent Sample T-Test)

Tes hasil beajar menggunakan pembelajaran mind mapping

\begin{tabular}{|l|c|}
\hline Thitung & \multicolumn{1}{|c|}{2,374} \\
\hline Ttabel & \multicolumn{1}{|c|}{1,670} \\
\hline Sig. (2-tailed) & \multicolumn{1}{|c|}{0,000} \\
\hline Keterangan & $\begin{array}{l}\text { Pengaruh metode pembelajaran } \\
\text { terhadap hasil belajar matematika }\end{array}$ \\
\hline
\end{tabular}

H0 : tidak ada Pengaruh metode pembelajaran mind mapping terhadap hasil belajar matematika

H1 : ada Pengaruh metode pembelajaran mind mapping terhadap hasil belajar matematika

Kriteria pengambilan keputusan:

jika thitung $<$ ttabel atau nilai signifikan ( $\rho$-value) $>0,05$ maka H0 diterima

jika thitung $\geq$ ttabel atau nilai signifikan $(\rho$-value $) \leq 0,05$ maka H0 ditolak.

Hasil perhitungan pada Tabel 5 diperoleh nilai thitung $(2,374) \geq$ ttabel $(1,670)$. Berdasarkan nilai thitung dan ttabel tersebut dapat disimpulkan bahwa H0 ditolak dan $\mathrm{H} 1$ diterima yang artinya adalah ada Pengaruh metode pembelajaran mind mapping terhadap hasil belajar matematika. Adapun pengaruhnya sebesar $7,8 \%$.

Tabel 6. Hasil Uji T (Independent Sample T-Test)

\begin{tabular}{|l|c|}
\hline \multicolumn{2}{|c|}{ Tes hasil belajar kelas esperiment berdasarkan jenis kelamin } \\
\hline Thitung & 0,402 \\
\hline Ttabel & 1,692 \\
\hline Sig. (2-tailed) & 0,000 \\
\hline Keterangan & Pengaruh jenis kelamin terhadap hasil belajar matematika \\
\hline
\end{tabular}

H0 : tidak ada pengaruh jenis kelamin terhadap hasil belajar matematika

H1 : ada Pengaruh jenis kelamin terhadap hasil belajar matematika

Kriteria pengambilan keputusan:

jika thitung < ttabel atau nilai signifikan $(\rho$-value $)>0,05$ maka H0 diterima 
jika thitung $\geq$ ttabel atau nilai signifikan $(\rho$-value $) \leq 0,05$ maka H0 ditolak.

Hasil perhitungan pada Tabel 6 diperoleh nilai thitung $(0,402)<$ ttabel $(1,692)$. Berdasarkan nilai thitung dan ttabel tersebut dapat disimpulkan bahwa H0 diterima dan H1 ditolak yang artinya adalah tidak ada Pengaruh jenis kelamin terhadap hasil belajar matematika. Namun terdapat sedikit perbedaan antara nilai rata-rata siswa perempuan dan nilai rata-rata siswa laki-laki. Hal tersebut dapat ditunjukkan bahwa nilai rata-rata siswa perempuan lebih besar dari nilai rata-rata siswa laki-laki yaitu $82,50>83,94$.

\section{Kesimpulan}

Berdasarkan hasil analisis data, diperoleh beberapa kesimpulan sebagaiberikut:

1. Dari hasil output uji independent sample test (uji-t) SPSS 20 yaitu nilai thitung $\geq$ ttabel $(2,374 \geq$ 1,670) dan signifikansinya sebesar 0,021. Disimpulkan bahwa H0 ditolak dan H1 diterima yang artinya ada pengaruh metode pembelajaran mind mapping terhadap hasil belajar matematika siswa

2. Besarnya pengaruh metode pembelajaran mind mapping terhadap hasil belajar matematika siswa kelas VIII SMP Negeri 10 Jember adalah sebesar 7,89\%.

3. Dari hasil output uji independent sample test (uji-t) SPSS 20 yaitu nilai thitung $\geq$ ttabel $(0,402<1,692)$ dan signifikansinya sebesar 0,691. Disimpulkan bahwa H0 diterima dan H1 ditolak yang artinya tidak ada pengaruh jenis kelamin terhadap hasil belajar matematika siswa.

4. Pada uji independent sample test (t-test) SPSS 20 memberikan kesimpulan tidak ada pengaruh jenis kelamin terhadap hasil belajar matematika siswa, maka besarnya pengaruh jenis kelamin terhadap hasil belajar matematika siswa tidak dihitung. Namun terdapat sedikit perbedaan antara nilai rata-rata tes hasil belajar siswa perempuan dan laki-laki. Hal tersebut sebenarnya muncul karena perbedaan pola pikir yang dialami siswa laki-laki dan siswa perempuan yang mengakibatkan perbedaan gaya berpikir.

\section{Daftar Pustaka}

Ahmadi, Abu dan Supriyono, Widodo. (2008). Psikologi Belajar edisi revisi. Jakarta: PT. Rineka Cipta.

Depdiknas. (2003). Undang-Undang RI No 20 Tahun 2003. Tentang Sistem Pendidikan Nasional.

Ekawati dan Wulandari. (2011). Perbedaan Jenis Kelamin Terhadap Kemampuan Siswa Dalam Mata Pelajaran Matematika (Study Kasus Sekolah Dasar).

Hasbullah. (2005). Dasar-Dasar ilmu Pendidikan. Jakarta: PT. Raja Grafindo Persada.

Kasanah. (2012). Pengaruh Kolaborasi Pembelajaran Mind mappp Dan Problem possing Terhadap Prestasi Belajar Matematika Pada Materi Segitiga Siswa Kelas VIII SMPN 1 Sumbergempol. 